\title{
On a new species of spider crab \\ (Crustacea, Brachyura, Majidae) from the Northeast of Brazil
}

\author{
Cheruparambil Sankarankutty ${ }^{1,2}$ \\ Alexander C. Ferreira 1, 2 \\ Inailson M.C. da Cunha 1,3
}

\begin{abstract}
A new species of Podochela Stimpson, 1860, P. meloi sp. $\mathbf{n}$., collected from one of the estuaries of the State of Rio Grande do Norte, Brazil is described with illustrations showing its distinguishing features. A key to the species is provided.

KEY WORDS. Podochela meloi sp. n., new species, Northeast Brazil
\end{abstract}

A survey of the decapod fauna of the sublittoral region of the estuaries of the State of Rio Grande do Norte, Brazil initiated in 1998 has provided interesting results. Of the four estuaries under investigation the estuaries near the cities of Macau and Galinhos presenting hypersaline conditions due to their proximity to the salinas provided the material for the present study. Among the several species collected, a species of the spider crab which cannot be assigned to any known species of Podochela Stimpson, 1860 was collected. This account describes in detail a new species, Podochela meloi sp. $\mathbf{n}$.

Of a total of 14 species of Podochela described by RathBun (1925), $P$. algicola (Stebbing, 1914), P. gracilipes Stimpson, 1871 and P. riisei Stimpson, 1860 were recorded by her from Brazil. Subsequently, COELHO described three new species from Brazil, P. minuscula and P. brasiliensis in 1972 and P. atlantica in 1997. MELo (1996) mentions all these species in his account of the brachyuran fauna, except $P$. atlantica, and also lists these in the Catalogue of Crustacea of Brazil (MELo 1998). The new species described here will be the seventh from the Brazilian waters.

\section{Key to the identification of species of Podochela occurring in Brazil (Adapted from the key of MELO 1996)}

1. Branchial margin smoothly rounded and convex lacking lateral angular

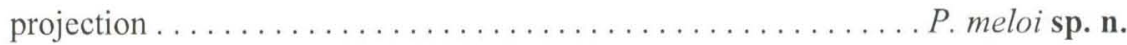

- Branchial and hepatic margins with distinct angular projection ...........

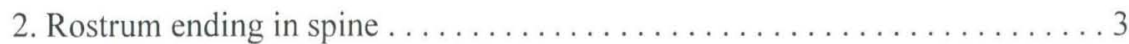

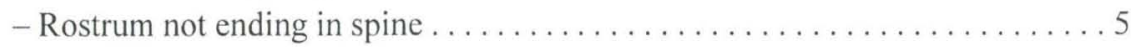

1) Departamento de Oceanografia e Limnologia, Universidade Federal do Rio Grande do Norte. Praia de Mãe Luiza, Via Costeira, 59014-100 Natal, Rio Grande do Norte, Brazil.

2) Bolsista do CNPq.

3) Bolsista PIBIC/CNPq. 
3. Pterygostomian tooth present visible in dorsal view .......... P. atlantica

- Pterygostomian tooth absent $\ldots \ldots \ldots \ldots \ldots \ldots \ldots \ldots \ldots \ldots \ldots$

4. Cardiac region elevated. Large hiatus between fingers in adult male; propodus of first pair of walking legs three times length of dactylus ......P. gracilipes

- Cardiac region not elevated. Without hiatus between fingers of adult male; propodus of first pair of walking legs 2.5 times length of dactylus ........

P. minuscula

5. Rostrum oval

- Rostrum large and triangular. Length of first pair of walking legs twice the length of carapace, including rostrum ............... brasiliensis

6. Length of first pair of ambulatory legs 2.5 times length of carapace including

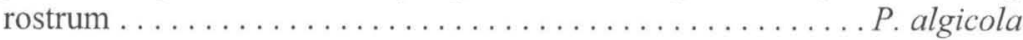

- Length of first pair of ambulatory legs 3 times length of carapace, including rostrum . . . . . . . . riisei

\section{Podochela meloi sp. $\mathbf{n}$.}

Figs 1-2

Type locality. Estuary near Macau, Rio Grande do Norte, Brazil ( $5^{\circ} 04^{\prime} S$ $5^{\circ} 08^{\prime} \mathrm{S} ; 36^{\circ} 35^{\prime} \mathrm{W}-36^{\circ} 30^{\prime} \mathrm{W}$ ).

Holotype. A male specimen deposited in the National Museum of Rio de Janeiro (Ref. No. MNRJ-137769), measuring $5.6 \mathrm{~mm}$ in carapace length and 4.0 $\mathrm{mm}$ in carapace width.

Paratypes. Five males and seven females; a female specimen measuring 5.5 $\mathrm{mm}$ in carapace length and $4.0 \mathrm{~mm}$ in carapace width, deposited in the Museum of Zoology, University of São Paulo (Ref. No. MZUSP/13192) and sever al specimens in the collection of Department of Oceanography and Limnology, Natal; largest specimen being a male measuring $7.8 \mathrm{~mm}$ in carapace length and $5.5 \mathrm{~mm}$ in carapace width.

Habitat. Occurring in the sublittoral region where the substratum is composed of broken stones and molluscan shells with algal growth. The area is also subjected to hypersaline conditions.

Etymology. Named after Prof. Dr. Gustavo A.S. Melo in recognition of his valuable contribution to Brazilian carcinology.

Description. Carapace pyriform in shape (Fig. 1B); rostrum in male long tapering gradually to a blunt tip reaching to the middle of second segment of antennal peduncle (Fig. 1A) in female short almost triangular hardly reaching beyond distal end of first segment of antennal peduncle (Fig. 1C, D); frontal region with a pair of oval whitish marking - distinct in some while faint in others and separated from with a raised and oval shaped gastric region; cardiac region similarly raised and separated from intestinal region by deep groove; rostrum long and tapering with rounded tip and reaching almost to middle of second antennal peduncle in male or conical and short reaching only as far as distal end of first peduncular segment of 

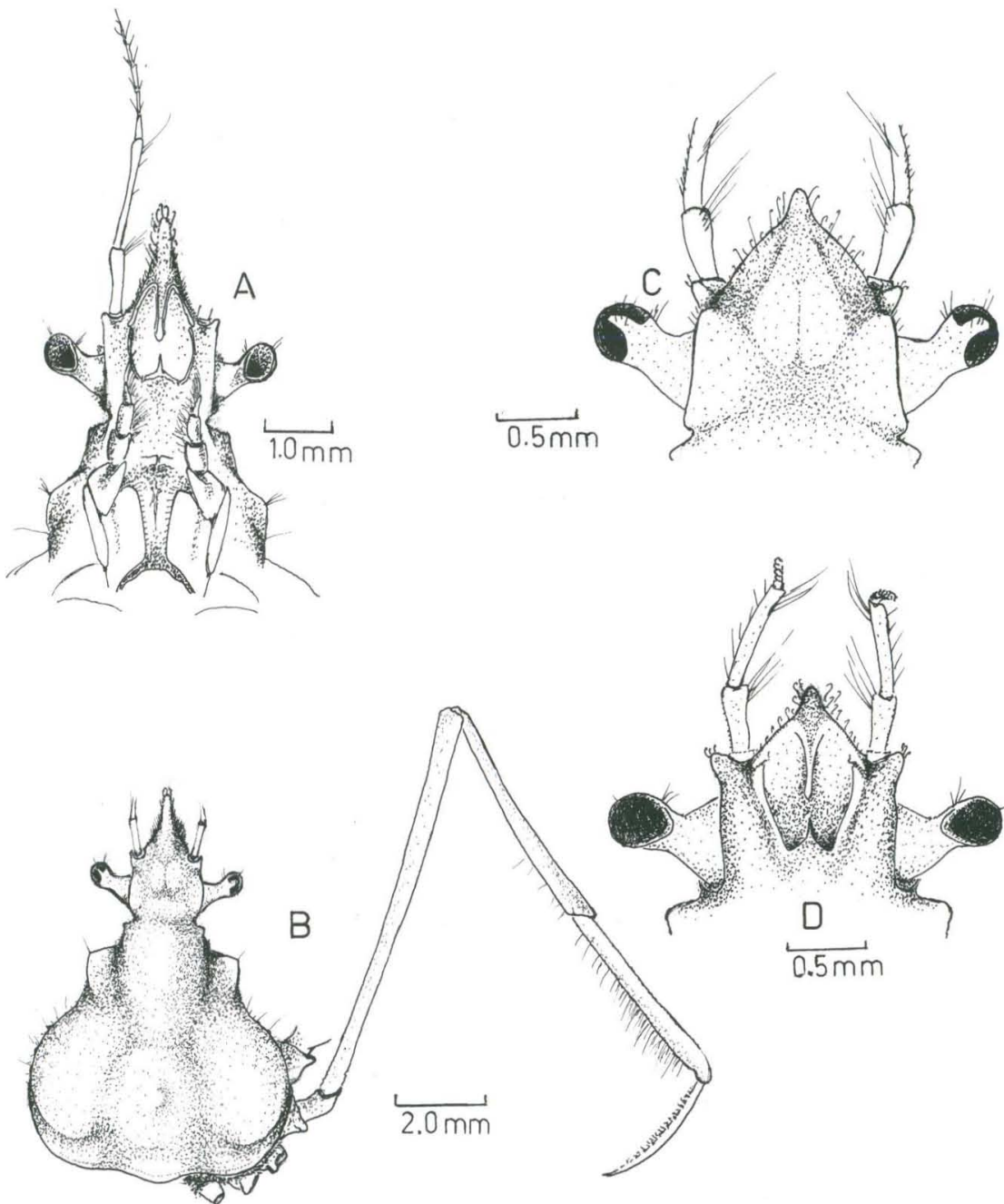

Fig. 1. Podochela meloi sp. n.. (A-B) male paratype: (A) ventral view of anterior part of specimen; (B) dorsal view of carapace with first walking leg; $(C-D)$ female paratype: (C) dorsal and (D) ventral views of anterior part of carapace.

antenna in female; eyes projecting laterally; supraorbital margins almost parallel; post-orbital tooth small behind a restriction - more conspicuous in male; margin of hepatic region with a triangular projection while branchial region lacking lateral projections, latter with smoothly rounded and bulging margin; two-segmented antennal peduncle with second segment distinctly longer than first; merus of third maxilliped triangular with palp attached to distal middle part (Fig. 2A). First sternal segment divisible into two parts -anterior part upturned by almost 90 degrees from posterior half, anterior part often with a median bottle-shaped marking in the middle, 
posterior end of the anterior half with a pair of tubercles; pterygostomian region with two tubercles, anterior one almost in line with distal outer angle of ischium of third maxilliped, in some only first tubercle recognisable.

Chelipeds equal in both sexes though much smaller in female.

Male cheliped (Fig. 2B, C). Merus sub-cylindrical only a little longer than half length of propodus with sparsely distributed setae; carpus short and with a distinct tooth near the distal end on ventral margin; propodus long and swollen inwardly sweeping towards tip of fixed finger, tuberculated on all sides with three larger tubercles on outer margin, ventral surface with tubercles extending in a line to fixed finger but reducing in size towards distally, fingers toothed all along its length on cutting edge (Fig. 2C), one large almost conical tooth near base of fixed finger and one or two on the movable finger. An additional internal row of teeth on both fingers with space in between rows covered with short setae.

Female cheliped: propodus not swollen and cutting edges of fingers armed with only one row of teeth.

Walking legs (Fig. 1B) reducing in size from first to last, dactylus sickleshaped, with two rows teeth on ventral margin (Fig. 2E) and terminating in a pointed claw, space between two rows of teeth covered with short setae.

Male abdomen (Fig. 2D) with six distinct and separate segments, first longer than second to fifth but narrower than second and third, width of abdomen narrowing from third to fifth, terminal segment only marginally longer than broad with slightly diverging border up to middle with conical distal half. Female abdomen with free first four segments steadily increasing in width from first to distal, distal two segments fused and enlarged.

First male pleopod (Fig. 2F) smoothly curving outwards from base and with a slightly enlarged distal end, inner margin with smaller setae and outer margin with longer setae towards base.

\section{DISCUSSION}

The genus Podochela contains an assemblage of species with variations in the shape of rostrum, presence or absence of a post-orbital tooth, shape and size of chelipeds and walking legs. Of the six species of Podochela occurring in Brazil, $P$. minuscula and $P$. gracilipes have prominent rostrum, latter with a narrower and more pointed one. P. meloi shares this characteristic with the above two species. However, a certain degree of variations are clearly evident among the specimens collected here which indicates sexual dimorphism, with males having tapering and long rostrum while female tends to have shorter and more conical rostrum. Absence of an angular lateral projection in the hepatic and branchial region is characteristic feature unique to $P$. meloi.

Absence of any post-orbital tooth is a characteristic which it shares with $P$. brasiliensis and $P$. riisei. Podochela meloi also lacks the sub-chelate walking legs present in $P$. brasiliensis and $P$. minuscula. With regard to the characteristics of chela, P. meloi comes close to that of P. latimanus Rathbun (RATHBUn 1925, fig. 14) though the former has more tubercles on the lateral sides. GARTH (1958, Part 2, 


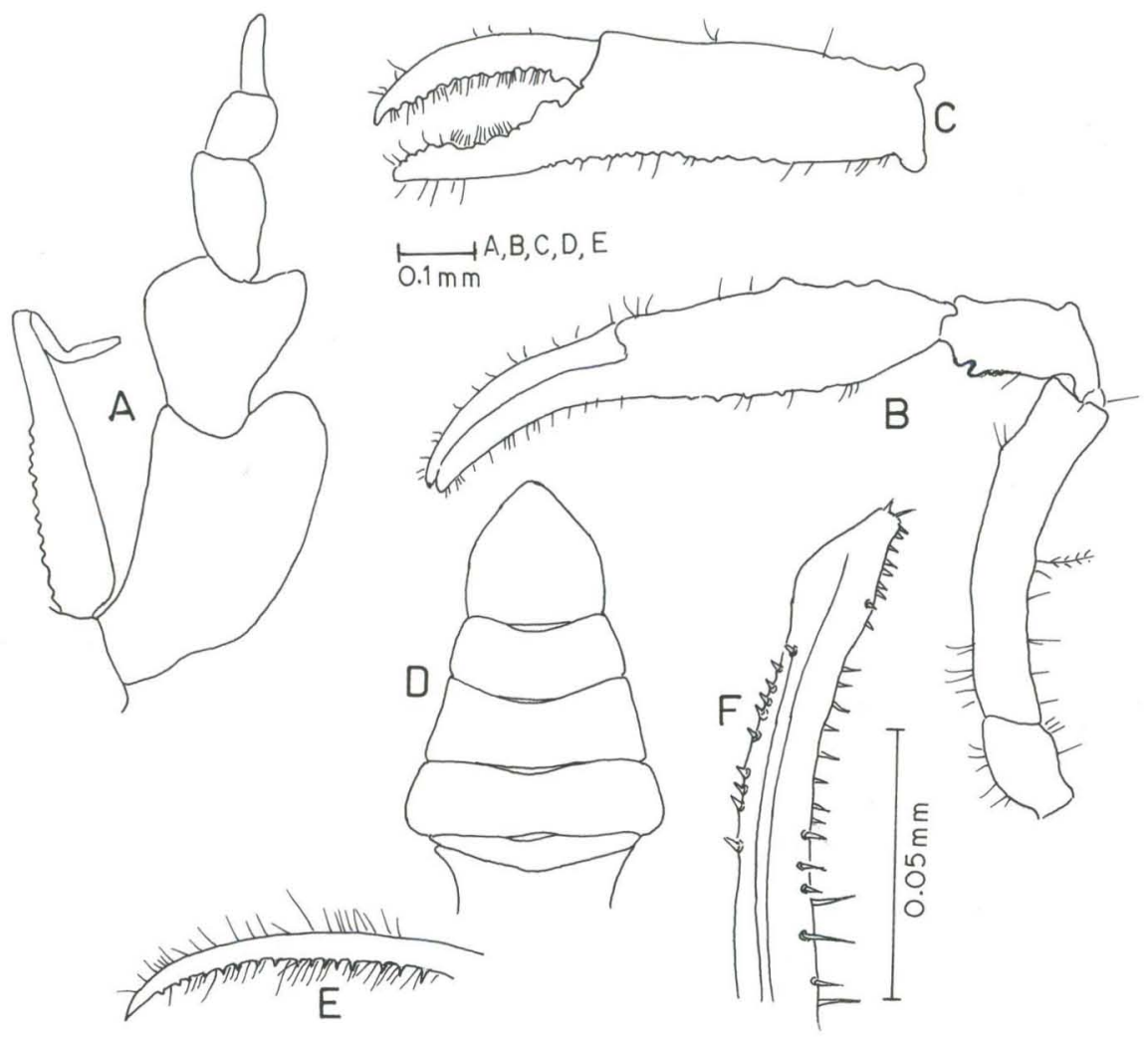

Fig. 2. Podochela meloi sp. n., male paratype: (A) third maxilliped; (B) cheliped; (C) chela; (D) abdomen; (E) Dactylus of walking leg; $(F)$ Ventral view of left first male pleopod.

PI. H), in his treatise on the Brachyura of the Pacific coast of America, provides illustrations of the first male pleopod of nine species ( $P$. lobifrons Rathbun; $P$. schmitti Garth; P. angulata Finnegan; P. latimanus (Rathbun); P. veleronis Garth; $P$. hemphilli (Lockington), $P$. vestita (Stimpson), $P$. margaritaria Rathbun and $P$. ziesenhennei (Garth). Subsequently, WiLLiams (1984) also illustrates this appendage of three more species ( $P$. gracilipes, $P$. riisei and $P$. sidneyi Rathbun) of which two occur in Brazil, $P$. gracilipes and $P$. riisei. They all share a characteristic shape - tapering distal part with a subterminal lateral lobe having a rounded end. A simplified first male pleopod lacking a lateral lobe is another feature which separates P. meloi from the rest.

ACKNOWLEDGEMENTS. The authors are grateful to CNPq for the award of a fellowship, to CAPES and the British Council for supporting the project which facilitated a visit to The Natural History Museum, London (C.S.) to finalise the paper. Senior author is also very much thankful to Dr. Paul Clark for the hospitality and valuable help received during his visit to The Natural History Museum. 


\section{REFERENCES}

Coelho, P.A. 1972. Descrição de três espécies novas de Majidae do Brasil (Decapoda: Brachyura).

Trabs Oceanogr. Univ. Fed. Pernambuco, Recife, 13: 119-132.

1997. Description of Podochela (Anisonotus) atlantica, sp. n., found in the Brazilian and

Uruguayan coasts (Crustacea, Decapoda, Majidae). Trabs Oceanogr. Univ. Fed. Pernambuco,

Recife, 25: 223-226.

Garth, J.S. 1958. Brachyura of the Pacific coast of America. Oxyrhyncha. Allan Hancock Pac. Exp.,

Los Angeles, 21 (1/2): 1-854.

MELo, G.A.S. 1996. Manual de identificação dos Brachyura (Caranguejos e Siris) do litoral brasileiro. São Paulo, Pleiade/FAPESP, 603p.

1998. Malacostraca - Eucarida. Brachyura: Oxyrhyncha and Brachyrhyncha, p. 455-515.

In: P.S. Young (Ed.). Catalogue of Crustacea of Brazil. Rio de Janeiro, Museu Nacional, $\mathrm{XVII}+717 \mathrm{p}$.

Rathbun, M.J. 1925. The spider crabs of America. Bull. U.S. natn. Mus., Washington, 129: 1-613.

Williams, A.B. 1984. Shrimps, lobsters, and crabs of the Atlantic coast of the Eastern United States,

Maine to Florida. Washington, D.C., Smithsonian Press, 550p.

Recebido em 10.VIII.2000; aceito em 01.VI.2001. 